\title{
Coral cavity sponges depend on reef-derived food resources: stable isotope and fatty acid constraints
}

\author{
Fleur C. van Duyl • Leon Moodley • Gerard Nieuwland • Lennart van Ijzerloo • \\ Rob W. M. van Soest • Marco Houtekamer · Erik H. Meesters • \\ Jack J. Middelburg
}

Received: 28 April 2010/Accepted: 16 March 2011/Published online: 12 April 2011

(C) Springer-Verlag 2011

\begin{abstract}
The diet of cavity sponges on the narrow fringing reefs of Curaçao, Caribbean was studied. The origin and resources of the bulk food of these sponges, i.e., dissolved organic matter (DOM), were identified using stable carbon and nitrogen isotopes and fatty acid biomarkers. We found that phytoplankton and its derived DOM from the adjacent open sea and from reef overlying water is not the main source of food for most of the sponges examined nor is bacterioplankton. Interestingly, dual stable isotope signatures $\left(\delta^{13} \mathrm{C}_{\mathrm{org}}, \delta^{15} \mathrm{~N}_{\mathrm{org}}\right)$ and fatty acid biomarkers appoint coral mucus and organic matter derived from crustose coralline algae (CCA) as probable food sources for encrusting sponges. Mucus-derived DOM may contribute up to $66 \%$ to the diet of examined sponges
\end{abstract}

Communicated by U. Sommer.

F. C. van Duyl $(\bowtie) \cdot$ G. Nieuwland

Royal Netherlands Institute for Sea Research,

P.O. Box 59, 1790 AB Den Burg, Texel, The Netherlands

e-mail: fleur.van.duyl@nioz.nl

L. Moodley $\cdot$ L. van Ijzerloo $\cdot$ M. Houtekamer

J. J. Middelburg

Netherlands Institute of Ecology (NIOO),

Korringaweg 7, 4401 NT Yerseke, The Netherlands

J. J. Middelburg

Faculty of Geosciences, University of Utrecht,

Budapestlaan 4, 3584 CD Utrecht, The Netherlands

E. H. Meesters

Wageningen IMARES, P.O. Box 167, Location Texel,

Landsdiep 4, 1797SZ 't Horntje, 1790 AD Den Burg,

The Netherlands

R. W. M. van Soest

Zoological Museum, University of Amsterdam,

P.O. Box 94766, 1090 GT Amsterdam, The Netherlands based on results of dual isotope mixing model analysis. The contribution of CCA (as purported representative for benthic algae) was smaller with values up to $31 \%$. Together, mucus- and CCA-derived substrates contributed for $48-73 \%$ to the diet of sponges. The presence of the exogenous fatty acid 20:4 $\omega 6$ in sponges, which is abundant in coral mucus of Madracis mirabilis and in CCA, highlights these reef-derived resources as sources of nutrition for DOM feeding cavity sponges. The relatively high concentrations of exogenous 20:4 $1 \omega 6$ in all sponges examined supports our hypothesis that the bulk of the food of the cavity sponge community is reef-derived. Our results imply that cavity sponges play an important role in conserving food and energy produced within the reef.

\section{Introduction}

Sponges play an important role in the benthic-pelagic coupling on coral reefs (Lesser 2006). The sponge community sequesters and processes organic matter and as such conserve energy and nutrients for the reef ecosystem. It is generally assumed that sponges on the fore-reef slope mainly trap allochthonous organic matter that may compensate the losses of material from reef ecosystems (e.g., Richter et al. 2001; Atkinson and Falter 2003; Ribes et al. 2005). Most reef sponges are extremely efficient in filter feeding (e.g., Reiswig 1974; Lesser 2006). They preferably filter the picoplankton fraction from the flowing water (e.g., Pile 1999; Ribes et al. 2003, 2005). The major food resource of coral reef sponges, however, may well be dissolved organic matter (Reiswig 1990; Yahel et al. 2003). Various encrusting high microbial abundance sponges (HMA sponges, sensu Hentschel et al. 2003) in coral cavities are fueled mainly by dissolved organic matter 
(DOM) (De Goeij et al. 2008a). Encrusting sponges cover together with coralline algae $>50 \%$ of the walls in coral cavities, caves, and undersides of corals (Vasseur 1974; Richter and Wunsch 1999; Wunsch et al. 2002; Scheffers et al. 2004). This cryptic surface of 3-dimensionally well-developed reefs may exceed the open reef surface (Ginsburg 1983; Richter et al. 2001; Scheffers et al. 2003). The sheer size of this reef habitat already preludes the grand role of its biota in organic matter cycling. DOM removal by the cryptic biota on coral reefs can be huge (up to $500 \mathrm{mmol} \mathrm{C} \mathrm{m}^{-2}$ cryptic surface $\mathrm{d}^{-1}$ ), with cavity sponges accounting for $70 \%$ of the consumed DOM in coral reef cavities (De Goeij and Van Duyl 2007; De Goeij et al. 2008a).

These recent findings draw direct attention to the origin and sources of DOM on coral reefs. Phytoplankton (including photoautotrophic bacteria) usually is the main source of reactive DOM in oligotrophic ocean water; it releases DOM as photosynthetic product or through food web processes and lysis (Carlson 2002). On coral reefs extra sources of reactive DOM include release of DOM by corals through mucus production (Johannes 1967; Richman et al. 1975; Crossland et al. 1980; Naumann et al. 2010) and extracellular release of DOM by benthic algae (e.g., Wada et al. 2007; Haas et al. 2010). The main consumers of reactive DOM are usually heterotrophic bacteria (e.g., Harvey et al. 2006 and references therein) that may compete with sponges for DOM. The fate of mucus and dissolved organic matter in reef overlying waters has been ascribed to consumption and mineralization by bacteria in the reef ambient water and in sediments (e.g., Gast et al. 1999; Ferrier-Pagès et al. 2000; Van Duyl and Gast 2001; Wild et al. 2004). The first indication that reef-derived DOM may also be assimilated by higher trophic levels came from the abundance of the dietary fatty acid biomarker 20:4 $\omega 6$ in the encrusting DOM feeding cavity sponge Halisarca caerulea (De Goeij et al. 2008b). This fatty acid is especially abundant in corals (Latyshev et al. 1991) and in coralline algae, Rhodophyta (Viso and Marty 1993) and its presence in sponges suggests that reefderived organic matter may be an important food source for coral reef sponges.

This study aims (1) to determine whether cavity sponges mainly rely on reef-produced or open water-derived dissolved organic matter and (2) to identify key sources of DOM for cavity sponges. As putative food compounds different fractions of suspended matter, bacterioplankton, coral mucus, and coralline algae as proxies for DOM were analyzed. Through stable isotopes and fatty acid biomarkers, we characterized energy sources of cavity sponges collected from coral reefs and open water on the southwest coast of Curaçao, Caribbean $\left(12^{\circ} 12^{\prime} \mathrm{N}\right.$, $\left.68^{\circ} 56^{\prime} \mathrm{W}\right)$. Stable isotopes are a classical way to trace food sources of aquatic animals (Peterson and Fry 1987). The carbon and nitrogen stable isotope signatures of 12 sponge species were compared with those of putative food compounds. Fatty acid biomarkers have been repeatedly used as source-specific indicators of dissolved and particulate organic matter both in environmental and in food web studies (e.g. Hall et al. 2006; Thurber 2007). The FA pattern of six sponge species and three types of reef food resources were analyzed, and the relative input of different sources to the diet of the sponges was determined.

\section{Materials and methods}

Sampling sites and sample collection

Samples were collected from March 14 to 22, 2006, along four transects perpendicular to the SW coast of Curaçao (Fig. 1). Transects were placed 3-7 km apart from SE to NW along the coast at Lagun Jan Thiel (LJT), at the ocean Cruise Terminal in Otrabanda (CT), at Buoy 1 (B1) of the Carmabi reef close to Piscaderabaai, and at Slangenbaai (SB). Transects from the shore to open water cross the narrow fringing reefs and water masses representative for the variation in coral community composition and water quality along the SW coast of Curaçao (Van Duyl 1985; Gast et al. 1999; Van Duyl and Gast 2001). Along each transect (LJT, CT, B1, and SB), we sampled 2 stations:

1. an off-shore open water station about 1-2 km distance from the reef where water was collected at $15-17 \mathrm{~m}$ depth in the blue water and

2. a coral reef station where we collected bottom water at 15-17 m depth on the fore-reef slope, approximately $0.5 \mathrm{~m}$ above the coral bottom.

Water samples were taken with a $6 \mathrm{~L}$ Niskin bottle operated by a SCUBA diver. The Niskin bottle was

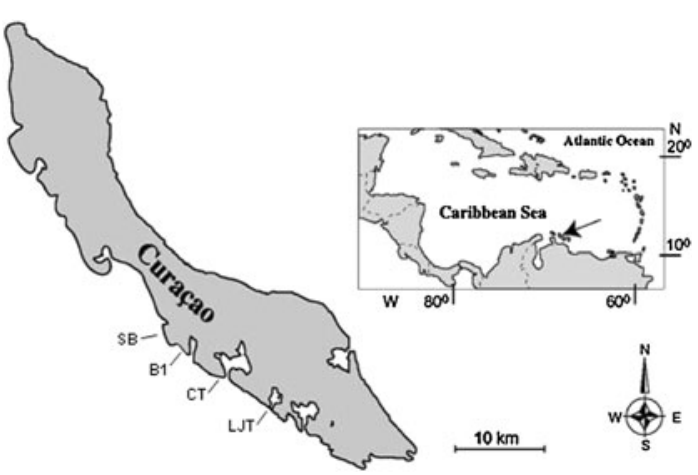

Fig. 1 Position of sampling transects (LJT, CT, B1, and SB) along the southwest coast of Curaçao, with an inset of the geographic position of the island in the Caribbean 
repeatedly filled and hauled on board a small open boat and emptied in a clean and sample washed $20 \mathrm{~L}$ container. At each station $(n=8)$, we collected $20 \mathrm{~L}$. On the fore-reef slope stations $(n=4)$, we collected a few small pieces of the stony corals Montastraea annularis and Madracis mirabilis (also Siderastrea siderea and Porites astreoides but only at B1) between 15 and $17 \mathrm{~m}$ depth, which were kept in seawater under natural light conditions until mucus collection on the next day. From the entrance of coral cavities at $15-17 \mathrm{~m}$ depth on the fore-reef slope, we chiseled crusts of calcareous algae. From the same cavities, various species of encrusting sponges were collected, up to eight different species per station. Specimens were chiseled from the walls and collected in plastic bags while SCUBA diving.

\section{Sample treatment}

The 20-L water samples were filtered over 47-mm-diameter combusted glass microfiber filters (Whatman), first over a GFC filter (nominal pore size $1.2 \mu \mathrm{m}$ ) and then over a GFF filter (nominal pore size $0.7 \mu \mathrm{m}$ ). After sea water filtration, filters were shortly washed with Milli-Q water (MQ) to remove salt and were dried at $50^{\circ} \mathrm{C}$ in a stove and stored in aluminum foil in the freezer until processing. The remaining bacterioplankton in the GFF filtrate was concentrated with a Vivaspin filter cartridge driven by a Master Volt tube pump. The concentrate was subsequently filtered over a $0.2 \mu \mathrm{m}$ pore size 25 -mm-diameter Anopore disc (aluminum oxide membrane filter, Whatman). The discs were briefly washed with MQ after seawater filtration and dried at $50^{\circ} \mathrm{C}$ in a stove $(12 \mathrm{~h})$. After drying, the filter was crumbled in a clean acid-washed glass funnel, the integrated polypropylene support ring of the filter was removed and the filter fragments were transferred to combusted silver capsules, which were closed with tweezers. Subsequently, the folded capsules were placed in coded trays and stored in the freezer until processing.

Live corals were air-exposed during mucus collection and positioned upside down connected to a stand. After shortly spraying the live coral tissue with MQ, the mucus produced by the coral was collected via an acid-washed glass funnel in combusted glass vials. After collection of approximately $2 \mathrm{~mL}$ mucus per coral, mucus samples were dried in a stove at $50^{\circ} \mathrm{C}$ before being stored dry in the freezer. Mucus samples were prepared in duplicate.

The cavity sponges and coralline algae were quickly washed with MQ to remove salt and the tissue was subsequently removed from the underlying substratum by knife and scalpel. Small pieces were fixed in ethanol $(80 \%)$ for taxonomical identification of the different sponge species. The rest of the pieces were collected in combusted glass vials dried at $50^{\circ} \mathrm{C}$ and stored dry in the freezer.
Sponges and putative food sources were subject to stable isotope analysis. Both carbon and nitrogen (except for bacteria for which only $\delta^{13} \mathrm{C}_{\text {org }}$ was measured) isotopic composition of the samples were determined using a Fisons $\mathrm{CN}$ analyser coupled on line via a Finnigan conflo 2 interface, to a Finnigan Delta $\mathrm{S}$ mass spectrometer. The carbon and nitrogen isotope ratios are expressed as $\delta^{13} \mathrm{C}_{\mathrm{org}}$ and $\delta^{15} \mathrm{~N}$ relative to the Vienna Pee Dee Belemnite standard and air, respectively, and the standard error of the measurements is $\sim 0.15 \%$. All carbon isotope samples (except bacteria that were caught on aluminum filters) were acidified (tissue directly with acid and glass filters in acid vapor) prior to measurements and corrected for individual sets of blanks (isotope mass balance corrections). Seawater as source of carbonates leading to possible enrichment of $\delta^{13} \mathrm{C}_{\mathrm{org}}$ in case of un-acidified aluminum bacteria filters was eliminated by the rinse with MQ water at the end of filtration. $\delta^{15} \mathrm{~N}$ values represent total nitrogen.

The dried sponge, coralline algae, and mucus material were first homogenized in a mortar. For isotope measurements, adequate amount of material was transferred to pre-combusted silver boats for acidification within cups, followed by oven drying to remove excess acid. From the remaining grounded material, samples from the B1 reef station were also analyzed for their total fatty acid composition using a method of one-step procedure of fatty acid extraction and methylation (Masood et al. 2005). We extracted three times $10 \mathrm{mg}$ dry material of each individual sample. Fatty acid extraction and preparation of methyl esters (FAME) were carried out according to Masood et al. (2005) with reagent volumes adapted for use in $2.5-\mathrm{mL}$ GC-vials using FAME C19:0 as internal standard to calculate concentration of FAs (Van Gaever et al. 2009). These individual samples were analyzed separately for their FA compositions employing a Large Volume Splitless injection method on a Thermo Finnigan Trace Ultra GC. Main items of this method are the large volume liner with glass wool, pre-column deactivated silica $5 \mathrm{~m} \times 0.53 \mu \mathrm{m}$, and analytical column SGE BPX-70 $50 \mathrm{~m} \times 0.32 \mathrm{~mm} \times 0.25 \mu \mathrm{m}$. The identification of FAMES was based on the comparison of retention times with authentic commercially available reference material and standards. Fatty acid source designation was achieved using data on distinctive FA for bacteria, algal carbon, and higher organisms (e.g., Parrish et al. 2000; Boschker and Middelburg 2002; Volkman 2006).

Statistical analyses

We ran one- and two-way ANOVAs with non-transformed stable isotope data to determine whether variations in stable isotopes of sponges were due to sponge species and/or sponge location assuming no interaction effects (not enough replication for testing interaction). The Tukey's 
HSD method was used for pair wise comparisons of different sponge species (multiple comparisons of means). ANOVA's were also run for isotope signals of reef and open water-derived suspended matter.

The SIAR stable isotope mixing model analysis (Parnell et al. 2010) was applied to investigate probable solutions for the diet of sponges based on dual stable isotope data of four sources (GFC and GFF fractions of suspended matter, crustose coralline algae, and coral mucus). We used the following trophic enrichment factors with standard deviations for the sponges: $3.5 \pm 0.5$ for $\delta^{15} \mathrm{~N}$ and $1 \pm 1$ for $\delta$

${ }^{13} \mathrm{C}$ (Vander Zanden and Rasmussen 2001; Behringer and Butler IV 2006). The SIAR model takes data on organism isotopes and fits a Bayesian model to their dietary habits based upon a Gaussian likelihood with a mixture dirichletdistributed prior on the mean. Model fitting is via Markov Chain Monte Carlo (MCMC) which produces simulations of plausible values for each dietary source consistent with the data. The software package SIAR (Stable Isotope Analysis in R) is freely available from the package section of the Comprehensive $\mathrm{R}$ Archive Network websitehttp://cran.r-project.org/ (Parnell and Jackson 2010).

Fatty acid composition patterns were explored with multivariate analyses of FAs composition profiles (nontransformed percentage abundance) using the program PRIMER Version 5 (Clarke and Gorley 2006). Multidimensional scaling (MDS plots) of FA composition and dual isotope label patterns were compared for six sponge species and the three different reef-derived resources (CCA, mucus of M. annularis, and mucus of M. mirabilis). Similarities between FA profiles were investigated using the SIMPER (Similarity of Percentages) function, and statistical differences were determined using the ANOSIM (Analysis of Similarities) function.

\section{Results}

The sponge species collected on the reef stations were identified on basis of their tissue and skeletal characteristics. Twelve different sponge species were recorded. Sponges had $\delta^{13} \mathrm{C}_{\text {org }}$ values ranging from $-17.2 \%$ (Chondrilla caribensis, Ruetzler et al. 2007) to $-20.7 \%$ (Scopalina ruetzleri) and $\delta^{15} \mathrm{~N}$ values ranging from $2.9 \%$ (Monanchora arbuscula) to 7.1\% (Scopalina ruetzleri) (Table 1). Variations in $\delta^{13} \mathrm{C}_{\mathrm{org}}$ and $\delta^{15} \mathrm{~N}$ data were significantly related to sponge species (ANOVA, $F_{(5,17)}=$ 30.3 and $F_{(5,17)}=15.8, P<0.01$ for both) and not to reef station $\left(F_{(3,17)}=1.16\right.$ and $F_{(3,17)}=0.83, P>0.35$ for both). Significant differences in $\delta^{13} \mathrm{C}$ as well as $\delta^{15} \mathrm{~N}$ $(P<0.05)$ were found between $S$. ruetzleri and $H$. caerulea, $S$. ruetzleri and Niphates erecta, $N$. erecta and M. arbuscula, which were sampled at three to four reef sites (Table 1). Differences in dual stable isotope values between sponge species were small when compared to isotope values of sources. Therefore, the sponge data of the different transects were combined in the Fig. $2 \mathrm{a}, \mathrm{b}$. The stable isotope signals of particulate organic matter size fractions were not significantly different between the open water and reef water (ANOVA, $P>0.05$ ), but were kept separate in Fig. 2a, b. Figure 2a shows that open water and reef water bacteria have on average slightly different $\delta^{13} \mathrm{C}$ signatures. Variations in $\delta^{13} \mathrm{C}_{\text {org }}$ values of bacterioplankton were large between stations (LJT and SB vs. CT and B1, Table 2). Only the reef water bacteria of station $\mathrm{SB}\left(\delta^{13} \mathrm{C}\right.$ : $-17.9 \%$ ) were in trophic reach of sponges $(<2 \%$ difference). The sponge trophic range overlaps with the range of coralline algae (average $\delta^{13} \mathrm{C}$ of $-16.9 \pm 4.2 \%$ ). Variations in isotope signals were also large between algal samples from different stations. Coral mucus of Montastraea annularis and Madracis mirabilis was on average heavier in ${ }^{13} \mathrm{C}_{\text {org }}$ content than the sponges (Table 2). Coral mucus and coralline algae are potential sponge food because of a trophic level $\delta^{15} \mathrm{~N}$ increase of 3-4\%o (Fig. 2b).

Pooled analysis with the mixing model (no distinction between sites or sponge species) show that mucus (MU1 and MU2 combined) contributed to the average cavity sponge diet between 44 and 57\% (=95\% low and high confidence limits, mode $50 \%$ ), CCA between 0 and $10 \%$ (mode 2\%), and the different SPM fractions between 0 and $33 \%$ (mode $7 \%$ ) for GFC and 14 and $47 \%$ (mode $37 \%$ ) for GFF (Table 3a). Of the overall diet $51 \%$ (mode) was reefderived. Variation in the $\delta^{13} \mathrm{C}$ and $\delta^{15} \mathrm{~N}$ of CCA between stations was large. Therefore, we ran the SIAR mixing model also separate for the stations for which CCA data were available, CT and B1 (Tables 2, 3b, c). Pooled analysis of sponges at CT (no distinction between sponge species) reflected a higher CCA contribution (between 6 and $43 \%$, mode $31 \%$ ) than mucus ( $0-46 \%$, mode $17 \%)$. Together CCA and mucus contributed $48 \%$ (mode) to the diet of sponges. Suspended matter supplemented the diet between 0 and $40 \%$ for the GFC fraction (mode 17\%) and $11-55 \%$ for the GFF fraction (mode of GFC and GFF fractions together $51 \%$, Table $3 \mathrm{~b}$ ). At B1, where coral cover is higher than at CT (Van Duyl 1985; pers comm), the diet of an average cavity sponge (no distinction between sponge species) was dominated by reef-derived sources $(73 \%)$ with coral mucus and CCA contributing for 60 and 13\% (mode) and with 95\% confidence between $50-68 \%$ and $0-30 \%$, respectively (Table 3c). The contribution of suspended matter fractions GFC and GFF was within the $0-28 / 0-30 \%$ range (modes 11 and $5 \%$ ), respectively.

For six sponge species, CCA and mucus of two coral species at B1 dual isotopes as well as fatty acid patterns were measured (Fig. 3; Table 4). A total of 43 FAs were 
Table 1 Sponge species collected at four reef stations with their respective average isotope signatures

\begin{tabular}{|c|c|c|c|c|c|c|c|c|c|}
\hline \multirow[t]{2}{*}{ Cryptic biota } & \multirow{2}{*}{$\begin{array}{l}\text { Station } \\
\text { Code }\end{array}$} & \multicolumn{2}{|c|}{$\begin{array}{l}\text { LJT } \\
\text { Lagun Jan Thiel }\end{array}$} & \multicolumn{2}{|c|}{$\begin{array}{l}\mathrm{CT} \\
\text { Cruise terminal }\end{array}$} & \multicolumn{2}{|c|}{$\begin{array}{l}\text { B1 } \\
\text { Carmabi reef }\end{array}$} & \multicolumn{2}{|c|}{$\begin{array}{l}\text { SB } \\
\text { Slangenbaai }\end{array}$} \\
\hline & & $\overline{\delta^{13} \mathrm{C}}$ & $\delta^{15} \mathrm{~N}$ & $\delta^{13} \mathrm{C}$ & $\overline{\delta^{15} \mathrm{~N}}$ & $\delta^{13} \mathrm{C}$ & $\overline{\delta^{15} \mathrm{~N}}$ & $\delta^{13} \mathrm{C}$ & $\delta^{15} \mathrm{~N}$ \\
\hline Halisarca caerulea & SP1 & -18.79 & 3.69 & & & -18.45 & 4.12 & -18.33 & 3.16 \\
\hline$n=7$ & & -18.48 & 4.02 & & & -18.20 & 4.09 & & \\
\hline & & -17.87 & 4.07 & & & -18.73 & 4.63 & & \\
\hline $\begin{array}{l}\text { Clathria (Thalysis) raraechelae } \\
n=1\end{array}$ & SP2 & & & & & -18.91 & 4.03 & & \\
\hline $\begin{array}{l}\text { Chondrilla caribensis } \\
n=1\end{array}$ & SP3 & & & & & -17.16 & 3.83 & & \\
\hline $\begin{array}{l}\text { Chelonaplysilla erecta } \\
n=1\end{array}$ & SP4 & & & & & -19.94 & 4.68 & & \\
\hline $\begin{array}{l}\text { Desmapsamma anchorata } \\
n=1\end{array}$ & SP5 & & & & & -18.81 & 5.61 & & \\
\hline Scopalina ruetzleri & SP6 & -19.76 & 5.90 & -20.26 & 4.85 & -20.79 & 5.48 & -20.02 & 6.13 \\
\hline$n=6$ & & & & & & -19.41 & 7.07 & -20.06 & 5.86 \\
\hline $\begin{array}{l}\text { Eurypon laughlini } \\
n=2\end{array}$ & & & & -18.95 & 5.67 & & & -18.51 & 5.78 \\
\hline Topsentia ophirhaphidites & & & & -19.63 & 5.37 & & & & \\
\hline$n=2$ & & & & -19.27 & 5.82 & & & & \\
\hline Niphates erecta & & -17.70 & 4.01 & -17.65 & 4.79 & -17.93 & 4.47 & -17.99 & 4.21 \\
\hline$n=6$ & & & & $\begin{array}{l}-17.97 \\
-18.00\end{array}$ & $\begin{array}{l}4.71 \\
4.71\end{array}$ & & & & \\
\hline $\begin{array}{l}\text { Callyspongia vaginalis } \\
n=2\end{array}$ & & -17.72 & 3.79 & -17.47 & 4.37 & & & & \\
\hline Monanchora arbuscula & & -20.38 & 3.83 & & & -20.40 & 3.42 & -19.82 & 3.28 \\
\hline$n=5$ & & -19.95 & 2.84 & & & & & -19.47 & 3.63 \\
\hline $\begin{array}{l}\text { Phorbas amaranthus } \\
n=1\end{array}$ & & & & & & -18.86 & 4.40 & & \\
\hline
\end{tabular}

Codes SP1-SP6 refer to sponges collected at B1 and correspond to sponge data presented in Fig. 3

identified. FAs in sources were also present in most sponges, but the diversity in FAs was higher in sponges. Differences between sources (CCA and mucus) and sponges in the fatty acid compositions are illustrated in Fig. 4. The Euclidean distances show that the FAs of sponges cluster together and are distinct from the sources. Main FAs of the sponge cluster included, in order of importance 16:0, 20:4 $\omega 6,18: 0,20: 5 \omega 3,18: 1 \omega 7 \mathrm{c}$, and branched 20:0 (phytanic acid) whereas in the case of the potential energy

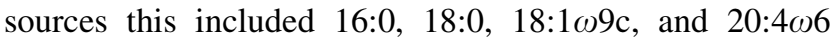
(Table 4). The source groups were significantly different (ANOSIM, Global $\mathrm{R}=0.8, P<0.05$ ) from the sponge group and SIMPER analysis revealed that the differences are the relatively higher percentage abundance of 16:0,

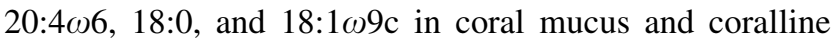
algae but higher percentage abundance of phytanic acid, 24:0 and 20:5 $\omega 3$ in the sponges. These 7 FAs together accounted for $\sim 60 \%$ of the FA dissimilarity (Table 4; Fig. 4). Among the three different sources, coralline algae, mucus of Montastraea annularis, and Madracis mirabilis, composition patterns were also significantly different (ANOSIM, Global $\mathrm{R}=1, P<0.05$ ). SIMPER analysis revealed two very dominant fatty acids in the coralline

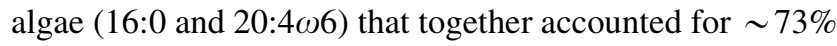
of the FA; in mucus from $M$. annularis (MU1), four abundant FAs made up 70\% (16:0, 18:0, 20:5 133 , and $18: 1 \omega 9 \mathrm{c})$; in mucus from $M$. mirabilis (MU2), three

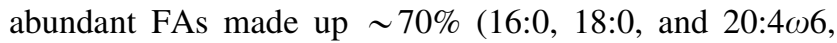
Table 2). The major FAs accounting for the dissimilarity between mucus from the two different coral species is the relatively higher percentage abundance of 20:4 106 and 18:0 in M. mirabilis (MU2) but a relatively higher percentage

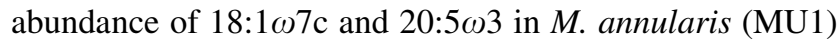
with these 4 FAs accounting for $\sim 60 \%$ of the dissimilarity between the coral species (Table 4 ). There was low similarity in FA patterns between most of the sponges. Three groups of sponges were distinguished among the 6 sponge species (Fig. 4: H. caerulea (SP1), C. caribensis (SP3) and 

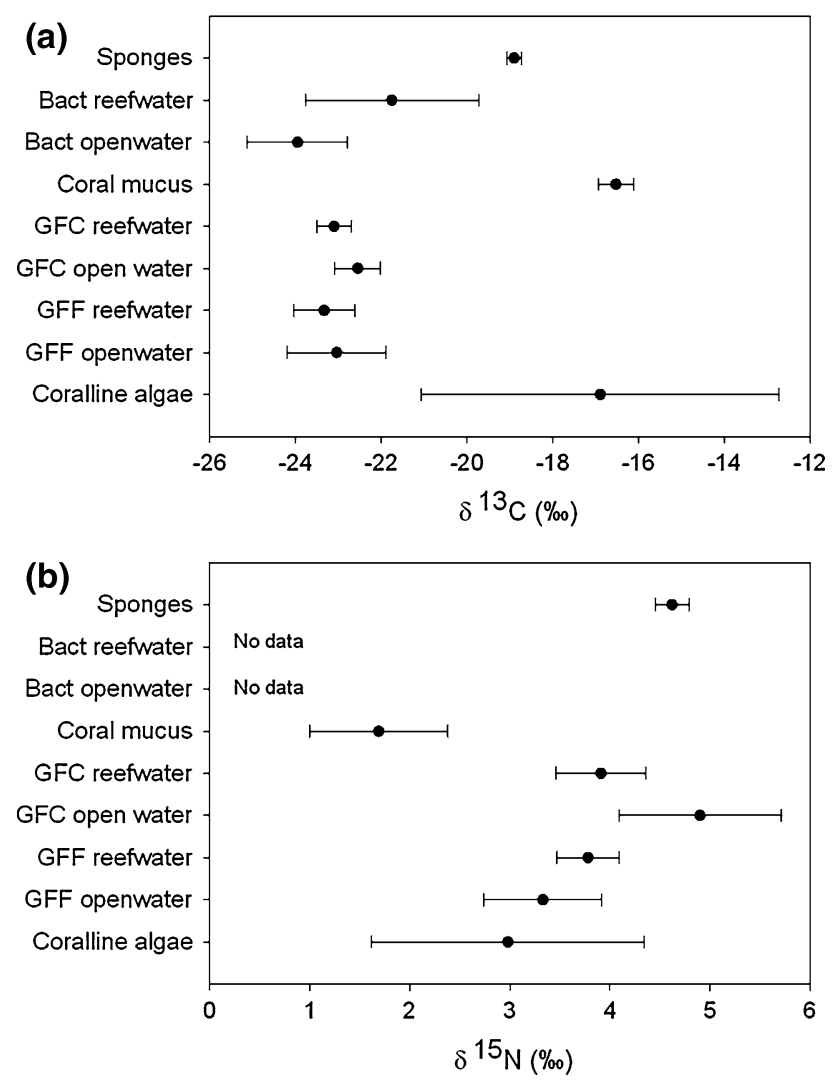

Fig. 2 Plots of carbon (a) and nitrogen (b) stable isotope signatures of material collected from the four reef and four open water stations (average and standard error). Sponges $(n=35)$, Bacteria (Bact $n=8$ ), Coral mucus $(n=9)$, Glass microfiber filters coarse (GFC) and fine (GFF) represent values of suspended matter (SPM) collected either from reef water or from open water offshore $(n=4$ or 5$)$. Crustose coralline algae from two reef stations $(n=3)$

C. erecta (SP4) make up the first group; $C$. raraechelae (SP2) and D. anchorata (SP5) the second and S. ruetzleri (SP6) the third group). SIMPER analysis revealed different combinations of FAs, in order of dominance, accounting for $\sim 70 \%$ of sponge group similarity: for the first group (SP1, SP3, and SP4) FAs 16:0, br 20:0 (phytanic acid), $18: 0,20: 4 \omega 6, \mathrm{i} 15: 0$, and 16:1 $\omega 7 \mathrm{c}$ are the main FAs. In the second group (SP2 and SP5) FAs 16:0, 20:4 $16,24: 0$, $18: 1 \omega 7 \mathrm{c}, 22: 0,20: 5 \omega 3$, and 20:6 63 determined primarily the composition pattern. In the third group (SP6), these were the five FAs: 16:0, 20:4 $\omega 6,18: 0,20: 5 \omega 3$, and 14:0 (Table 4).

For these three distinguished sponge groups at B1, we also ran the isotope mixing model (Table 5). Results show that the three groups make proportionally different use of the sources. The first group appears to rely mainly on reefderived sources (mucus and CCA, mode and mean both $>75 \%$ ). The second group probably relied less on mucus and more on CCA and used more plankton-derived food compared with group 1 . The diet of group $3(=S$. ruetzleri only) consists for about $51 \%$ (mean) of reef-derived and
$49 \%$ (mean) of suspended matter (plankton) derived food. Group 1 has a smaller centroid Euclidean distance (23.64) to the average mucus mixture than groups 2 and 3 (32.43 and 24.55) in Fig. 4. This concurs with a larger contribution of mucus $(66 \%)$ to the diet of group 1 than that of the other two groups (36 and 33\%) (Fig. 4; Table 5). The lower contribution of CCA in the diet of group $1(10 \%$ mode) compared to group 3 (19\% mode) was also reflected in Fig. 4. We did not find this for group 2, which had the longest Euclidean distance to CCA (41.81 vs. 33.78 of group 3 and 37.37 of group 1), while CCA-derived food comprised $22 \%$ in the diet of this group. To further explore the relation between the stable isotope and FA data sets, we compared the matrices of FAs and dual isotope signatures of sponges and reef resources (Figs. 3, 4) and found a significant correlation between the two matrices (PRIMER, Rho $=0.625, P=<0.01)$.

\section{Discussion}

Cryptic encrusting sponges living in coral cavities on the fore-reef slope of fringing reefs sequester most of their organic matter from the passing water. They efficiently filter the pico- and nanoplankton, but dissolved organic matter (DOM) appears to be the major resource of various sponge species living on the open reef and in coral cavities (Yahel et al. 2003; De Goeij et al. 2008a). The origin and source of this organic matter is unknown. It may be DOM released from phytoplankton, DOM supplied to the reef from outside or DOM released from the reef benthos. Gradients in DOM concentrations over the reef suggest that there is a net release of DOM from coral reef waters to adjacent open waters (Van Duyl and Gast 2001). Only $10-20 \%$ of the DOM in reef water appears to be available for sponges (De Goeij et al. 2008a). By analyses of dual stable isotope signatures $\left(\delta^{13} \mathrm{C}_{\text {org }}\right.$ and $\left.\delta^{15} \mathrm{~N}\right)$ and FA patterns of sponges and their potential food sources, we obtained circumstantial evidence that the reef itself mainly feeds her cavity sponges. This remarkable finding implies that cryptic sponges support reef internal nutrient recycling and conservation of reef organic matter.

It was surprising that none of the 12 sponge species examined appeared to live mainly on suspended particulate organic matter or DOM derived from this source. The $\delta^{13} \mathrm{C}_{\text {org }}$ values of the SPM fractions were in the range reported for marine suspended matter (Peterson and Fry 1987). Bacterioplankton values were within $2 \%$ of SPM in open water, which indicates that bacteria were the primary consumers of SPM. This makes it highly likely that SPM represents predominantly phytoplankton and that the bacterioplankton reflects the $\delta^{13} \mathrm{C}$ isotope ratio of reactive DOM released by phytoplankton (e.g., Harvey et al. 2006; 
Table 2 Average isotope signatures of putative food sources for sponges collected from reef stations LJT, CT, B1, and SB (replicates, $n=2-3$, standard errors range from 0 to 0.4 , not shown)

\begin{tabular}{|c|c|c|c|c|c|c|c|c|c|}
\hline \multirow[t]{2}{*}{ Substrate sources } & \multirow{2}{*}{$\begin{array}{l}\text { Station } \\
\text { Code }\end{array}$} & \multicolumn{2}{|c|}{$\begin{array}{l}\text { LJT } \\
\text { Lagun Jan Thiel }\end{array}$} & \multicolumn{2}{|c|}{$\begin{array}{l}\text { CT } \\
\text { Cruise terminal }\end{array}$} & \multicolumn{2}{|c|}{$\begin{array}{l}\text { B1 } \\
\text { Carmabi reef }\end{array}$} & \multicolumn{2}{|c|}{$\begin{array}{l}\text { SB } \\
\text { Slangenbaai }\end{array}$} \\
\hline & & $\delta^{13} \mathrm{C}$ & $\delta^{15} \mathrm{~N}$ & $\delta^{13} \mathrm{C}$ & $\delta^{15} \mathrm{~N}$ & $\delta^{13} \mathrm{C}$ & $\delta^{15} \mathrm{~N}$ & $\delta^{13} \mathrm{C}$ & $\delta^{15} \mathrm{~N}$ \\
\hline \multicolumn{10}{|l|}{ SPM-GFC } \\
\hline Open water & & -21.77 & 5.27 & -23.87 & 3.37 & -22.96 & 7.00 & -21.61 & 3.94 \\
\hline Reef water & & -23.72 & 4.51 & -23.38 & 5.17 & -23.83 & 3.67 & -22.53 & 2.66 \\
\hline Crevice water & & & & & & -21.40 & 2.96 & & \\
\hline \multicolumn{10}{|l|}{ SPM-GFF } \\
\hline Open water & & -20.86 & 3.81 & -23.92 & 1.97 & -25.87 & 2.84 & -21.52 & 4.69 \\
\hline Reef water & & -21.19 & 4.53 & -24.86 & 3.00 & -24.36 & 4.40 & -22.09 & 3.80 \\
\hline Crevice water & & & & & & -24.08 & 3.20 & & \\
\hline \multicolumn{10}{|l|}{ Bacteria } \\
\hline Open water & & -21.93 & nd & -26.02 & nd & -27.31 & nd & -19.42 & nd \\
\hline Reef water & & -15.36 & nd & -26.40 & nd & -27.41 & nd & -17.85 & nd \\
\hline \multicolumn{10}{|l|}{ Macroalgae } \\
\hline Coralline algae & $\mathrm{CCA}$ & & & -13.37 & 3.60 & -25.20 & 1.30 & & \\
\hline & & & & -12.12 & -4.05 & & & & \\
\hline \multicolumn{10}{|l|}{ Coral mucus } \\
\hline M. annularis & MU1 & -15.46 & 0.54 & -15.78 & 4.12 & -16.46 & -2.35 & -14.24 & 3.21 \\
\hline M. mirabilis & MU2 & -17.95 & 2.12 & -16.53 & 4.24 & -17.64 & 1.71 & & \\
\hline S. siderea & & & & & & -17.80 & 0.55 & & \\
\hline P. astreoides & & & & & & -16.87 & 1.11 & & \\
\hline
\end{tabular}

Suspended particulate matter (SPM) fractions collected on coarse (GFC) and fine (GFF) glass fiber filters. Bacterioplankton (Bacteria) was collected on aluminum oxide (anopore) membrane filters. Codes CCA and MU1, MU2 refer to data collected at B1 and correspond to data presented in Fig. 3

nd not done

Van den Meersche et al. 2009). The $\delta^{13} \mathrm{C}$ of SPM did not change during passage over the reef, for instance by obtaining a typical $\delta^{13} \mathrm{C}$ SPM reef signal $(-17$ to $-20 \%$ : Land et al. 1975; Fry et al. 1982; Yamamuro et al. 1995). The $\delta^{15} \mathrm{~N}$ of SPM did not change either and remained $\sim 4 \%$. Moreover, at two of the four stations (CT and B1) comparable $\delta^{13} \mathrm{C}_{\text {org }}$ values of predominantly heterotrophic bacterioplankton $(-26,-27 \%$, Table 2) between open water and reef bottom water suggest that this bacterioplankton remained dependent on phytoplankton DOC. Such low $\delta^{13} \mathrm{C}$ values have been reported, for e.g., Synechococcus $\left(\delta^{13} \mathrm{C}-33\right.$ to $-25 \%$, Brutemark et al. 2009) and Prochlorococcus, both abundant in reef and open water along Curaçao (Van Duyl et al. 2002). Residence time of the SPM and bacterioplankton in reef overlying waters may have been too short for changes in isotopic ratios either due to rapid water exchange with the open water and/or due to SPM removal by benthic suspension feeders. Phytoplankton concentrations in reef surrounding waters in Curaçao are usually low (van Duyl et al. 2002), and the organic matter demand of cryptic biota, cryptic sponges in particular, is high. Cavity biota between 10 and $15 \mathrm{~m}$ depth on the fore-reef slope in Curaçao consume on average $350 \mathrm{mmol} \mathrm{C} \mathrm{m} \mathrm{C}^{-2} \mathrm{~d}^{-1}$ of which cavity sponges consume on average $256 \mathrm{mmol} \mathrm{C} \mathrm{m}^{-2} \mathrm{~d}^{-1}$ (73\%) with the DOC fraction comprising $>90 \%$ of the diet (De Goeij et al. 2008a). This organic matter supply is orders of magnitude higher than the supply of pelagic primary production to reefs (Richter et al. 2001; Genin et al. 2009). It is evident that the supply of open water-derived phytoplankton and its DOM release is insufficient to satisfy the total organic carbon requirements of coral reef cavity sponges. In accordance, the isotope mixing model results confirmed a SPM contribution of less than $<50 \%$ in the diet of most sponges. This implies that the examined sponges with average $\delta^{13} \mathrm{C}_{\text {org }}$ of $-18.9 \%$ and $\delta^{15} \mathrm{~N}$ of $4.6 \%$ mainly assimilate other sources than pelagic primary production.

Benthic primary production is the most likely other source of DOM for sponges. Presence of distinct reactive DOM in reef bottom water compared to open water was demonstrated by the increased $\delta^{13} \mathrm{C}$ value of bacterioplankton at two of the four stations (LJT and SB). 
Table 3 Dual isotope mixing model analyses of the diet of sponges Sources Low 95\% High 95\% Mode Mean Mode\% Mean\%

\begin{tabular}{|c|c|c|c|c|c|c|}
\hline \multicolumn{7}{|c|}{ (a) Average diet of sponges (four stations) } \\
\hline GFC ro & 0 & 0.326 & 0.071 & 0.138 & & \\
\hline GFF ro & 0.140 & 0.474 & 0.371 & 0.321 & 44.2 & 45.9 \\
\hline $\mathrm{CCA}$ & 0 & 0.095 & 0.015 & 0.039 & & \\
\hline MucMix & 0.435 & 0.572 & 0.498 & 0.502 & 51.3 & 54.1 \\
\hline \multicolumn{7}{|c|}{ (b) Diet of sponges at $C T$} \\
\hline GFC ro & 0 & 0.402 & 0.170 & 0.194 & & \\
\hline GFF ro & 0.112 & 0.552 & 0.335 & 0.333 & 50.5 & 52.7 \\
\hline $\mathrm{CCA}$ & 0.063 & 0.428 & 0.308 & 0.254 & & \\
\hline MucMix & 0 & 0.455 & 0.172 & 0.218 & 48 & 47.2 \\
\hline \multicolumn{7}{|c|}{ (c) Diet of sponges at B1 } \\
\hline GFC ro & 0 & 0.275 & 0.106 & 0.122 & & \\
\hline GFF ro & 0 & 0.300 & 0.053 & 0.130 & 15.9 & 25.2 \\
\hline CCA & 0.001 & 0.301 & 0.131 & 0.155 & & \\
\hline MucMix & 0.502 & 0.682 & 0.596 & 0.593 & 72.7 & 74.8 \\
\hline
\end{tabular}

The sources comprise two suspended matter size fractions, GFC ro $>1.2 \mu \mathrm{m}$ and GFF ro $>0.7$ and $<1.2 \mu \mathrm{m}$ from reef overlying and open water (ro), CCA representing crustose coralline algae and MucMix representing coral mucus of two different coral species, $M$. annularis and M. mirabilis. The $95 \%$ credibility intervals are presented of the different sources as well as the mode and the mean. Mode\% and mean $\%$ show the contribution of plankton-derived (GFC and GFF) and reef-derived organic matter (CCA and MucMix) in the diet as \%

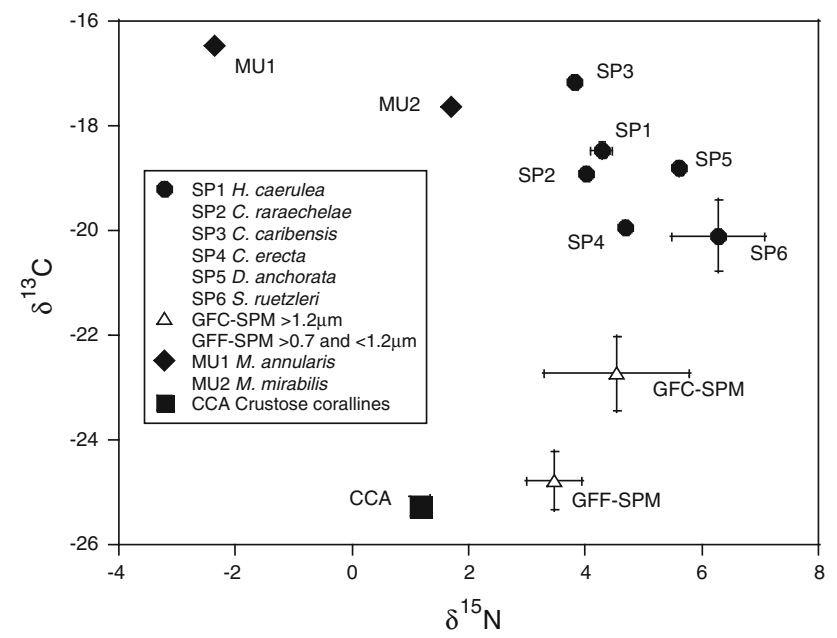

Fig. 3 Carbon and nitrogen isotopes of six sponge species (SP1-SP6) and putative organic matter sources for sponges at reef site B1. The average and standard error for SP1 $(n=3)$ and SP6 $(n=2)$, GFC$\operatorname{SPM}(n=3)$, GFF-SPM $(n=3)$ is presented. Other data points (SP2, 3, 4, and 5, CCA and mucus from two coral species, Montastraea annularis (MU1) and Madracis mirabilis (MU2) do not have replicates other than repetitive sample analysis of the same specimen). See also Tables 1, 2

Bacterioplankton apparently assimilated a source of carbon not available in the open water, a source, which may also be available to the DOM feeding cavity sponges. Benthic primary producers usually have higher $\delta^{13} \mathrm{C}_{\text {org }}$ values than pelagic primary producers (France 1995; Fry 2006). Thus, assimilation of benthic algae-derived reactive DOC may explain the elevated $\delta^{13} \mathrm{C}$ values in bacterioplankton in reef bottom water at LJT and SB. Bacteria respond quickly when exposed to changing resources in the vicinity of the reef bottom. Enhanced bacterioplankton production in reef bottom waters, cavity waters, and coral mucus point to the reef bottom as the source of inorganic nutrients and reactive DOM (Van Duyl and Gast 2001; Scheffers et al. 2005). Sponges and bacteria may compete for the released DOM. However, the $\delta^{13} \mathrm{C}$ reef signal of bacterioplankton $(-17.9$ to $-15.4 \%$ ) was higher than that of most examined sponges $(-20.8$ to $-17.2 \%$ ) suggesting that sponges and bacterioplankton may not fully depend on the same source of reef-derived DOM. Sponges may exploit a wider size range of the operationally defined DOM fraction than bacterioplankton (De Goeij et al. 2008a).

Benthic primary producers such as corals and benthic macroalgae have been reported to release reactive DOM (e.g., Crossland 1983, 1987; Wild et al. 2004, 2010; Haas et al. 2010; Naumann et al. 2010). The $\delta^{13} \mathrm{C}$ values of the benthic substrates (coral mucus of two dominant coral species and crustose coralline algae) were on average higher in $\delta^{13} \mathrm{C}$ than the SPM and open water bacterioplankton and were more in range of the sponge stable isotope signals. The $\delta^{15} \mathrm{~N}$ values of reef-derived substrates with values 3-4\%o lower than those of sponges on average suggest a direct trophic link (one trophic level distance). The lower $\delta^{15} \mathrm{~N}$ values of reef substrates versus open water substrates may be due to enhanced $\mathrm{N}_{2}$ fixation by the reef benthos (Davey et al. 2008; Lesser et al. 2007) compared with $\mathrm{N}_{2}$ fixation by microorganisms in open waters. Discharge from land or pollution may counteract this effect by introducing organic and inorganic $\mathrm{N}$ enriched in ${ }^{15} \mathrm{~N}$. This may partly explain the variations in $\delta^{15} \mathrm{~N}$ in mucus, coralline algae, and sponges between different stations.

The range of $\delta^{13} \mathrm{C}_{\text {org }}$ in crustose coralline algae (CCA) of -25.2 to $-12.1 \%$ was unexpectedly large, possibly due to the unique ontogeny of CCA. Younger portions of the CCA may have lower $\delta^{13} \mathrm{C}_{\text {org }}$ values than older portions possibly because rapid photosynthesis in younger parts depends more on respired $\mathrm{CO}_{2}$ than photosynthesis in older parts (Lee and Carpenter 2001). Anyway, the lower range of $\delta^{13} \mathrm{C}_{\text {org }}$ values of CCA was within $2 \%$ of our sponges. Moreover, the $\delta^{15} \mathrm{~N}$ of CCA (1.3-4.0\%) make it a likely food source for the majority of cavity sponges with 3-4\%o higher $\delta{ }^{15} \mathrm{~N}$ values than the CCA. Little is known of exudation of organic matter by CCA apart from the releases of allelochemicals (e.g., Kim et al. 2004). Total DOM release by CCA has not been determined as far as we know, but their productivity equals that of fleshy macroalgae and turf algae on reefs (Chrisholm 2003). Reported 
Table 4 Fatty acid composition of six sponge species (SP1-SP6, see Table 1), one crustose coralline alga (CCA) and mucus (MU) from two coral species (see Table 2), all collected from reef site B1

\begin{tabular}{|c|c|c|c|c|c|c|c|c|c|}
\hline & SP1 & SP2 & SP3 & SP4 & SP5 & SP6 & $\mathrm{CCA}$ & MU1 & MU2 \\
\hline i14: $0^{\mathrm{a}}$ & $0(0)$ & $0(0)$ & $0.7(0.02)$ & $0(0)$ & $0(0)$ & $0(0)$ & $0(0)$ & $0(0)$ & $0(0)$ \\
\hline $14: 0$ & $6.6(0.55)$ & $2.6(0.05)$ & $2.3(0.08)$ & $3.6(0.40)$ & $3.8(0.55)$ & $9.1(0.24)$ & $3.5(0.10)$ & $5.3(0.21)$ & $2.6(0.05)$ \\
\hline ai $15: 0^{\mathrm{a}}$ & $0.6(0.05)$ & $0(0)$ & $2.6(0.02)$ & $0.5(0.27)$ & $0.1(0.07)$ & $0.3(0.06)$ & $0.04(0.04)$ & $0(0)$ & $0(0)$ \\
\hline i15: $0^{\mathrm{a}}$ & $5.3(0.24)$ & $0.3(0.06)$ & $9.8(0.05)$ & $5.4(0.25)$ & $0.8(0.04)$ & $0.5(0.16)$ & $0(0)$ & $3.8(1.90)$ & $4.2(0.08)$ \\
\hline $15: 0$ & $1.2(0.11)$ & $0.5(0.01)$ & $1.1(0.07)$ & $1.4(0.07)$ & $1.7(0.15)$ & $7.5(0.23)$ & $0.3(0.07)$ & $0(0)$ & $0(0)$ \\
\hline i16: $0^{\mathrm{a}}$ & $0.6(0.08)$ & $0.4(0.02)$ & $1.3(0.02)$ & $0.4(0.20)$ & $0.7(0.05)$ & $1.9(0.05)$ & $0.3(0.02)$ & $0(0)$ & $0(0)$ \\
\hline $10 \mathrm{Me}-16: 0^{\mathrm{a}}$ & $0(0)$ & $0(0)$ & $0(0)$ & $0(0)$ & $0.4(0.07)$ & $0(0)$ & $0(0)$ & $0(0)$ & $0(0)$ \\
\hline $16: 2 \omega 6$ & $0(0)$ & $0(0)$ & $0(0)$ & $0(0)$ & $0(0)$ & $0(0)$ & $0(0)$ & $0(0)$ & $0.51(0.03)$ \\
\hline $16: 2 \omega 4$ & $0(0)$ & $0.2(0.03)$ & $0(0)$ & $0(0)$ & $0.5(0.00)$ & $0.1(0.09)$ & $0.04(0.04)$ & $0(0)$ & $0(0)$ \\
\hline $16: 1 \omega 5 \mathrm{c}$ & $0(0)$ & $0.7(0.03)$ & $0.9(0.03)$ & $0.4(0.18)$ & $0.6(0.03)$ & $0.4(0.02)$ & $0(0)$ & $0(0)$ & $0(0)$ \\
\hline $16: 1 \omega 7 \mathrm{c}^{\mathrm{a}}$ & $3.3(0.16)$ & $1.6(0.02)$ & $12.6(0.03)$ & $4.0(0.11)$ & $4.2(0.16)$ & $2.1(0.04)$ & $0.5(0.06)$ & $3.9(0.50)$ & $0.6(0.04)$ \\
\hline $16: 1 \omega 7 \mathrm{t}^{\mathrm{a}}$ & $0(0)$ & $0.15(0.02)$ & $0.79(0.01)$ & $0(0)$ & $0.1(0.07)$ & $0.3(0.04)$ & $0(0)$ & $0(0)$ & $0(0)$ \\
\hline $16: 0$ & $17.1(1.73)$ & $13.2(0.27)$ & $18.4(0.19)$ & $20.5(0.39)$ & $12.1(0.62)$ & $19.6(0.52)$ & $40.7(0.21)$ & $30.8(0.84)$ & $27.8(0.66)$ \\
\hline $10 \mathrm{Me}-17: 0^{\mathrm{a}}$ & $0(0)$ & $0(0)$ & $0.8(0.15)$ & $0(0)$ & $0(0)$ & $0(0)$ & $0(0)$ & $0(0)$ & $0(0)$ \\
\hline $17: 1 \omega 7 \mathrm{c}$ & $0.9(0.66)$ & $0.1(0.00)$ & $1.9(0.10)$ & $8.5(0.42)$ & $0.5(0.11)$ & $0.7(0.22)$ & $0.4(0.12)$ & $0(0)$ & $0(0)$ \\
\hline $17: 0$ & $1.9(0.08)$ & $0.5(0.04)$ & $0.5(0.49)$ & $2.6(0.13)$ & $1.4(0.00)$ & $0.5(0.09)$ & $0.3(0.00)$ & $0.5(0.03)$ & $0(0)$ \\
\hline i18: $0^{\mathrm{a}}$ & $0(0)$ & $0.6(0.05)$ & $0.3(0.05)$ & $0(0)$ & $0.6(0.09)$ & $0.4(0.02)$ & $0(0)$ & $0(0)$ & $0(0)$ \\
\hline $18: 5 \omega 3$ & $0.2(0.22)$ & $1.1(0.03)$ & $0.2(0.05)$ & $0(0)$ & $1.7(0.23)$ & $0.1(0.05)$ & $0.1(0.00)$ & $1.5(0.04)$ & $0(0)$ \\
\hline $18: 5$ & $0(0)$ & $0(0)$ & $0(0)$ & $0(0)$ & $0(0)$ & $0(0)$ & $0(0)$ & $2.1(1.03)$ & $0(0)$ \\
\hline $18: 3 \omega 6$ & $0.6(0.56)$ & $0.3(0.02)$ & $0.1(0.04)$ & $0(0)$ & $0(0)$ & $0(0)$ & $0(0)$ & $4.1(0.31)$ & $0(0)$ \\
\hline $18: 3 \omega 3$ & $0.5(0.25)$ & $0.1(0.07)$ & $0(0)$ & $0.8(0.21)$ & $0.3(0.26)$ & $0(0)$ & $0(0)$ & $0(0)$ & $0(0)$ \\
\hline $18: 2 \omega 6 \mathrm{c}$ & $1.8(0.12)$ & $0.8(0.07)$ & $0.3(0.02)$ & $2.2(0.09)$ & $0.6(0.30)$ & $0.9(0.06)$ & $0.8(0.02)$ & $0.4(0.20)$ & $0.8(0.05)$ \\
\hline $18: 1 \omega 7 \mathrm{c}$ & $5.7(0.12)$ & $9.7(0.06)$ & $3.3(0.10)$ & $5.5(0.04)$ & $6.6(0.15)$ & $2.0(0.06)$ & $4.5(0.05)$ & $8.1(0.33)$ & $0.7(0.03)$ \\
\hline $18: 1 \omega 9 \mathrm{c}$ & $2.5(0.50)$ & $1.9(0.06)$ & $1.9(0.11)$ & $4.2(0.14)$ & $1.4(0.26)$ & $2.0(0.08)$ & $11.2(0.10)$ & $9.1(0.32)$ & $7.3(0.12)$ \\
\hline $18: 0$ & $9.4(0.25)$ & $4.0(1.61)$ & $9.7(0.23)$ & $10.2(0.29)$ & $5.6(0.46)$ & $11.5(0.06)$ & $3.0(0.02)$ & $15.5(0.34)$ & $25.4(0.74)$ \\
\hline i20: $0^{\mathrm{a}}$ & $0.2(0.20)$ & $0.8(0.01)$ & $0(0)$ & $0(0)$ & $1.1(0.14)$ & $0(0)$ & $0(0)$ & $0(0)$ & $0(0)$ \\
\hline $20: 5 \omega 3$ & $4.5(0.26)$ & $6.3(0.24)$ & $3.4(0.01)$ & $3.0(0.25)$ & $5.0(0.36)$ & $11.7(0.26)$ & $0.1(0.05)$ & $11.0(0.15)$ & $4.4(0.44)$ \\
\hline $20: 4 \omega 3$ & $0(0)$ & $0.10(0.05)$ & $0(0)$ & $0(0)$ & $0.4(0.08)$ & $0.7(0.35)$ & $0.3(0.30)$ & $0(0)$ & $0(0)$ \\
\hline $20: 4 \omega 6$ & $10.6(0.68)$ & $11.1(0.24)$ & $9.1(0.25)$ & $8.1(0.11)$ & $10.7(0.48)$ & $15.2(0.27)$ & $32.2(0.75)$ & $0(0)$ & $15.0(0.34)$ \\
\hline $20: 3 \omega 6$ & $0.7(0.13)$ & $0.7(0.12)$ & $0.5(0.06)$ & $0.6(0.08)$ & $0.5(0.03)$ & $0.5(0.05)$ & $0.4(0.03)$ & $0(0)$ & $0(0)$ \\
\hline $20: 3 \omega 3$ & $0(0)$ & $0.1(0.07)$ & $0(0)$ & $0.1(0.12)$ & $0.3(0.13)$ & $0.1(0.13)$ & $0(0)$ & $0(0)$ & $0(0)$ \\
\hline $\begin{array}{l}\text { Phytanic } \\
\text { acid }\end{array}$ & $15.5(1.34)$ & $2.9(0.13)$ & $13.4(0.26)$ & $8.3(0.29)$ & $1.8(0.30)$ & $1.3(0.19)$ & $0.2(0.03)$ & $0(0)$ & $0(0)$ \\
\hline $20: 1 \omega 9 \mathrm{c}$ & $0.6(0.39)$ & $0.2(0.05)$ & $0.1(0.00)$ & $0(0)$ & $0.5(0.10)$ & $0.1(0.05)$ & $0.2(0.04)$ & $0(0)$ & $0.3(0.28)$ \\
\hline $20: 2 \omega 9$ & $0.3(0.15)$ & $0.3(0.05)$ & $0(0)$ & $0.8(0.02)$ & $0.9(0.40)$ & $2.6(0.04)$ & $0.1(0.04)$ & $0(0)$ & $0(0)$ \\
\hline 20:0 & $0.9(0.04)$ & $2.2(0.06)$ & $0.8(0.04)$ & $1.7(0.05)$ & $3.5(0.16)$ & $2.5(0.03)$ & $0.3(0.05)$ & $3.1(0.14)$ & $6.4(0.21)$ \\
\hline $22: 6 \omega 3$ & $1.0(0.01)$ & $8.4(0.14)$ & $0.1(0.06)$ & $2.6(0.27)$ & $3.6(0.28)$ & $1.9(0.02)$ & $0(0)$ & $0(0)$ & $0(0)$ \\
\hline $22: 5 \omega 3$ & $0(0)$ & $0(0)$ & $0.1(0.09)$ & $2.8(0.30)$ & $0(0)$ & $0(0)$ & $0.1(0.03)$ & $0(0)$ & $0(0)$ \\
\hline $22: 4 \omega 6$ & $0.5(0.06)$ & $1.9(0.14)$ & $0(0)$ & $0.6(0.58)$ & $0.3(0.12)$ & $0(0)$ & $0(0)$ & $0.9(0.44)$ & $1.9(0.14)$ \\
\hline $22: 1 \omega 11$ & $0.2(0.20)$ & $0.1(0.03)$ & $0.5(0.06)$ & $0.1(0.11)$ & $0(0)$ & $0(0)$ & $0.1(0.03)$ & $0(0)$ & $0(0)$ \\
\hline $22: 1 \omega 9 \mathrm{c}$ & $0(0)$ & $0(0)$ & $0.1(0.05)$ & $0(0)$ & $0(0)$ & $1.0(0.08)$ & $0.1(0.07)$ & $0(0)$ & $0(0)$ \\
\hline $22: 0$ & $1.9(0.18)$ & $4.2(0.25)$ & $0.7(0.03)$ & $0.4(0.19)$ & $18.1(0.89)$ & $0.8(0.20)$ & $0.2(0.05)$ & $0(0)$ & $2.2(0.09)$ \\
\hline $23: 0$ & $1.5(0.17)$ & $2.1(0.34)$ & $0.9(0.05)$ & $0.1(0.12)$ & $2.0(0.14)$ & $0.1(0.06)$ & $0(0)$ & $0(0)$ & $0(0)$ \\
\hline $24: 0$ & $3.5(0.31)$ & $20.3(0.96)$ & $1.1(0.10)$ & $0.6(0.06)$ & $7.8(0.32)$ & $1.8(0.04)$ & $0.3(0.05)$ & $0(0)$ & $0(0)$ \\
\hline$\%$ bact-spec & $6.6 / 9.9$ & $2.2 / 3.8$ & $16.2 / 28.7$ & $6.3 / 10.3$ & $3.7 / 7.8$ & $3.4 / 5.5$ & $0.3 / 0.8$ & $3.8 / 7.7$ & $4.2 / 4.8$ \\
\hline
\end{tabular}

Average $\% \pm \operatorname{SE}(n=3)$

${ }^{a}$ Bacteria-specific FA and last row is average \% bacteria specific FA (bact-spec) with/without inclusion of 16:1 $\omega 7 \mathrm{c}$ 


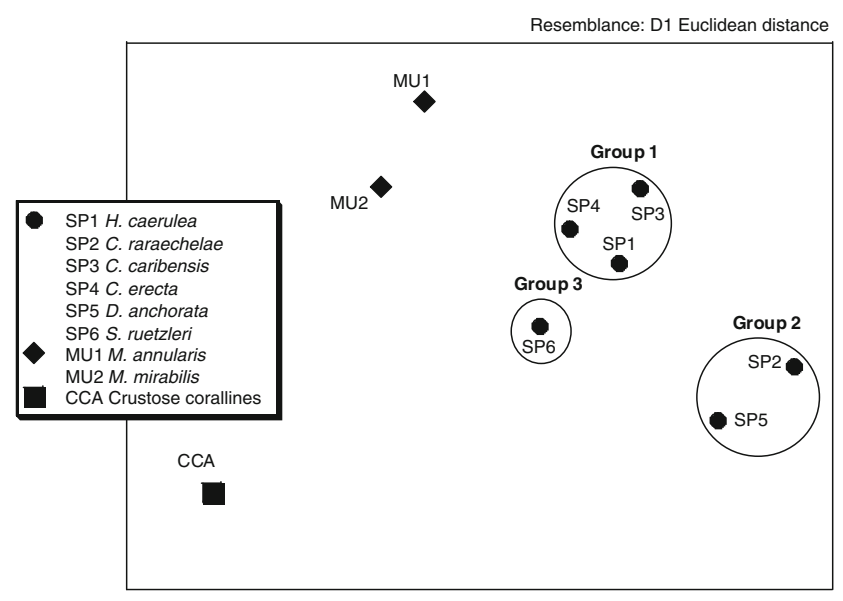

Fig. 4 Multidimensional scaling (MDS) plot showing similarity in fatty acid composition profiles of six sponge species (SP1-6), crustose coralline algae (CCA) and the mucus of two coral species, Montastraea annularis and Madracis mirabilis, at reef site B1 (see Table 4 for list of fatty acids)

Table 5 Results of dual isotope mixing model analyses for different sponge groups at B1

Sources Low 95\% High 95\% Mode Mean Mode\% Mean\%

(a) Diet of group 1

H. caerulea, C. caribensis, C. erecta (SP1, SP3, SP4)

$\begin{array}{lllllll}\text { GFC ro } & 0 & 0.284 & 0.036 & 0.117 & & \\ \text { GFF ro } & 0 & 0.244 & 0.036 & 0.104 & 7.2 & 22.1 \\ \text { CCA } & 0 & 0.286 & 0.095 & 0.132 & & \\ \text { MucMix } & 0.504 & 0.796 & 0.658 & 0.647 & 75.3 & 77.9\end{array}$

(b) Diet of group 2

C. raraechelae, D. anchorata (SP2, SP5)

$\begin{array}{lllllll}\text { GFC ro } & 0 & 0.432 & 0.167 & 0.216 & & \\ \text { GFF ro } & 0 & 0.43 & 0.202 & 0.208 & 36.9 & 42.4 \\ \text { CCA } & 0 & 0.451 & 0.219 & 0.219 & & \\ \text { MucMix } & 0.077 & 0.606 & 0.357 & 0.357 & 57.6 & 57.6\end{array}$

(c) Diet of group 3

S. ruetzleri (SP6)

GFC ro 0.003

0.487

$0.292 \quad 0.259$

GFF ro $0 \quad 0.453$

$\begin{array}{lll}0.285 & 0.232 & 57.7\end{array}$

49.1

CCA 0

0.421

$0.188 \quad 0.207$

MucMix 0.023

0.516

$\begin{array}{lll}0.327 & 0.302 & 51.5\end{array}$

50.9

For further explanation, see Table 3

$\delta^{13} \mathrm{C}$ values of -18.7 to $-16.8 \%$ for Dictyota $\mathrm{sp} .,-19.3 \%$ for Halimeda sp. (Raz-Guzman Macbeth and De la Lanza Espina 1991; Lepoint et al. 2000), and $\delta^{15} \mathrm{~N}$ values of $0.5-3 \%$ of macroalgae on coral reefs (Yamamuro et al. 1995; France et al. 1998) fall in the same range as CCA $\left(\delta^{13} \mathrm{C}_{\text {org }}-25.2\right.$ to $-12.1 \%$, $\delta^{15} \mathrm{~N} 1.3-4 \%$ ). Therefore, DOM released from these brown and green macroalgae may have also contributed to the isotope signal in sponges. Trophic transfers of organic matter derived from benthic macroalgae and mangroves, to sponges have been reported before (Behringer and Butler IV 2006; Granek et al. 2009) and appear to be important in the nutrition of sponges.

Unlike CCA, coral mucus has already been described as an important food source on coral reefs (Wild et al. 2004, 2010). About 56-80\% of coral mucus dissolves in sea water (Crossland et al. 1980; Wild et al. 2004) and may be a suitable source of DOM for cavity sponges. The $\delta^{13} \mathrm{C}$ of the mucus samples of Montastraea annularis and Madracis mirabilis (range -17.9 to $-14.2 \%$ ) is higher than that of most cavity sponges, implying that sponges do not feed exclusively on mucus or mucus-derived DOM. Coralderived organic matter is a reactive substrate for bacterioplankton growth (Ferrier-Pagès et al. 2000) and may have contributed to the $\delta^{13} \mathrm{C}$ reef signal of bacterioplankton at LJT $(-15.4 \%)$. The average $\delta^{15} \mathrm{~N}$ of mucus $(1.9 \%)$ and that of cavity sponges $(4.6 \%$ ) are consistent with mucus/ mucus-derived DOM as a food source for most cavity sponges.

It is evident that individually, neither phytoplankton, bacterioplankton, CCA (benthic macroalgae) nor coral mucus can account for the sponge dual isotope signatures. The isotope mixing model analysis showed that cavity sponges incorporate from half to three quarters of their organic matter from mucus and CCA (benthic macroalgae) with mucus as the dominant source of reef-derived organic matter (up to $66 \%$ of the diet). It appears that with decreasing coral cover the contribution of coral mucus to the diet of sponges decreases and shifts to a larger contribution of CCA (benthic macroalgae) and phytoplankton. At station CT with a lower coral cover than at the other reef stations, mucus only contributed $17 \%$ (mode) to the diet of sponges while the bulk food was provided by CCA including other benthic macroalgae (31\%) and small phytoplankton (34\%, GFF fraction). This was different at B1, where coral cover on the slope is relatively high (Van Duyl 1985; Bak and Nieuwland 1995) and the sponges reflect a diet of mainly mucus $(60 \%$, mode) with $13 \%$ CCA. This suggests that the sponge community is opportunistic and consumes OM according to availability irrespective of the DOM source. This does not imply that all examined sponge species at a particular reef site have similar diets. Significant differences in stable isotope values of different sponge species already suggest distinct diets. This is further corroborated with our FA profiles of sponges at B1.

The overall similarity in FA composition pattern of six examined sponge species at B1 was low. The three groups within these six sponge species (based on significantly different FA compositions) also had different diets according to the isotope mixing model analysis, implying differences in the proportional use of mucus, benthic algae 
(including CCA), and phytoplankton-derived DOM. This suggests that there is trophic niche segregation among sponges which may be an important factor facilitating co-existence of different sponge species (Thurber 2007). Furthermore, the differences in diet may to some extent be reflected in the FA compositions of sponge groups suggesting that the selected food resources may indeed form part of the diet of sponges.

The fatty acid profiles of our coral mucus and CCA sources resemble those reported for coral tissue and CCA (e.g., Latyshev et al. 1991; Viso and Marty 1993; Papina et al. 2003; Bachok et al. 2006). By assimilating these substrates, distinct FAs may conservatively be transferred to the consumer (Dalsgaard et al. 2003). Although many dominant FAs such as 14:0, 16:0, and 18:0 (Table 2) are common to many organisms, some FAs have been identified as potential tracer of food source in sponges. For this study area specifically, for example, De Goeij et al. (2008b) conclude from isotope tracer experiments that the dominant FA 20:4 66 found in the sponge Halisarca

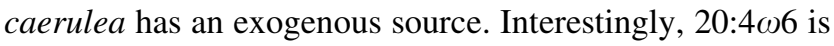
found dominant in all 6 sponge species examined and it is also dominant in CCA and M. mirabilis mucus. The high cover of CCA in cavities (30\% of the hard bottom surface in cavities, Scheffers et al. 2004), its close proximity to

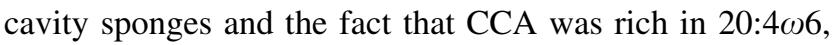
may have contributed to the 20:4 $\omega 6$ content in sponges. In sponge groups 2 and 3, this FA was the second most abundant ( $>10 \%$ of total FAs) and the diet of these sponge groups consisted for 19-22\% (mode) of CCA (including other macroalgae). In sponge group 1, the predominantly mucus feeding group, 20:4 16 was the third most abundant FA with a lower relative abundance than in the other groups $(<10 \%)$. This coincided with a lower contribution of CCA in their diet (10\% mode). Trophic transfer of this FA may be directly linked to the consumption of CCA as part of macroalgal-derived organic matter.

Phytanic acid, which can be considered as a sponge biomarker (De Goeij et al. 2008b) was the second most abundant FA in group 1. For its synthesis, degradation products of chlorophyll $a$ are required, possibly delivered to the sponge by sponge associated phototrophic microbes, considering the relatively high amount of the likely bacterial specific FA 16:1 $107 \mathrm{c}$ as well as the overall high $\%$ of bacteria specific FAs in group 1 (up to $29 \%$ compared with up to $10 \%$ of total FAs in the other groups, Table 4). Sponge species in group 1 indeed harbor-rich microbial communities (Hill et al. 2005; Erwin and Thacker 2007). Mutualism between sponges and their associated microorganisms may have influenced the diet of group 1 compared with groups 2 and 3. Weisz et al. (2007) show that sponges with high versus low abundances of associated microbes may have distinct diets. In line, we show that the diet of sponges (based on stable isotopes as well as FAs) varies with abundance of bacteria specific FAs. Interestingly, sponges with a relatively high abundance of associated microbes (group 1) appear to be more dependent on reefderived food than other sponges.

The FA 20:5 $\omega 3$, a dominant FA in (benthic) diatoms and the mucus of corals, particularly in mucus of M. annularis was most abundant in S. ruetzleri (group 3). The SIAR model analysis showed that the contribution of phytoplankton-derived food was highest in this sponge (mean $49 \%$ and mode $57 \%$, both plankton size fractions together), which may suggest that it feeds on diatoms or diatom-derived $\mathrm{OM}$ rich in 20:5 23 . The other sponge groups (1 and 2) may obtain 20:5 03 predominantly by consuming mucus considering the higher contribution of mucus and lower plankton-derived food in the diet of these groups than in the diet of S. ruetzleri (group 3). Diatomderived OM as well as mucus may have contributed to the abundance of 20:5 23 in sponges.

Considering the congruencies between the FA compositions and the dual stable isotope signals in the trophic transfer and relations between sources and consumers, it was not surprising that the matrices (based on Euclidean distances) of the reef sources and consumers of both approaches were significantly correlated. Both methods apparently lead to comparable results with FA composition and biomarkers identifying the food items of consumers, and evidencing trophic transfer and with dual stable isotope analyses estimating the contribution of the different sources to the diet of consumers. Results of both methods strongly support a trophic transfer from zooxanthellate corals and CCA to cavity sponges. The quantitative contribution of CCA to the diet of sponges remains unresolved, because its dual isotope signal overlaps with that of other benthic macroalgae.

\section{Conclusion}

Results unambiguously point to the reef benthos as the main source of organic matter for encrusting cavity sponges on coral reefs. The contribution of open water-derived organic matter as food for the cavity sponge community was usually less than $50 \%$. Food sources for sponges on the reef comprise DOM derived from coral mucus and benthic macroalgae (CCA). The prominent presence of a characteristic fatty acid of coral mucus and CCA, 20:4 66 in sponges further confirms this trophic transfer. These findings have implications for our understanding of organic matter turnover on reefs. Cryptic sponges apparently sequester and assimilate mainly DOM produced within the reef system. De Goeij et al. (2008b, 2009) found that the cavity sponge Halisarca caerulea converts assimilated DOM in sponge 
biomass and detrital material. Combining this with the knowledge that (1) the cover of cavity sponges is high on fore-reef slopes (Scheffers et al. 2004), (2) DOM assimilation by cavity sponges is high (De Goeij et al. 2008a), and (3) most of the OM assimilated by sponges is reef-derived (this study), we argue that cryptic sponges play a key role in conserving reef-produced DOM for the reef system by converting it into POM. Whether the "cryptic" sponge link in the coral reef food web is favorable for the coral reef health status remains to be investigated.

Acknowledgments We thank the CARMABI Foundation staff (Curaçao, Caribbean) and especially Carlos Winterdaal and Brian Leysner for their hospitality and support. Oscar Frans and Jasper de Goeij are acknowledged for support in the field. This study is financed by the 6th EU framework project SPONGES (project FP6-COOP-CT2005-017800 to FCVD) and in part supported by NWO (PIONEER to JJM). The reviewers are acknowledged for their comments that improved the MS considerably.

\section{References}

Atkinson MJ, Falter JL (2003) Coral reefs. In: Black KD, Shimmield GB (eds) Biogeochemistry of marine systems. Blackwell Publ Ltd, Oxford, pp 40-64

Bachok Z, Mfilinge P, Tsuchiya M (2006) Characterization of fatty acid composition in healthy and bleached corals from Okinawa, Japan. Coral Reefs 25:545-554

Bak RPM, Nieuwland G (1995) Long-term change in coral communities along depth gradients over leeward reefs in the Netherlands Antilles. Bull Mar Sci 56:609-619

Behringer DC, Butler IV MJ (2006) Stable isotope analysis of production and trophic relationships in a tropical marine hardbottom community. Oecologia 148:334-341

Boschker HTS, Middelburg JJ (2002) Stable isotopes and biomarkers in microbial ecology. FEMS Microbiol Ecol 40:85-95

Brutemark A, Lindehoff E, Graneli E, Graneli W (2009) Carbon isotope signature variability among cultured microalgae: influence of species, nutrients and growth. J Exp Mar Biol Ecol 372:98-105

Carlson CA (2002) Production and removal processes. In: Hansell D, Carlson CA (eds) Biochemistry of dissolved organic matter. Academic Press, Amsterdam, pp 91-152

Chrisholm JRM (2003) Primary productivity of reef-building crustose coralline algae. Limnol Oceannogr 48:1376-1387

Clarke KR, Gorley RN (2006) PRIMER v6: user manual/tutorial. PRIMER-E, Plymouth

Crossland CJ (1983) Dissolved nutrients in coral reef waters. In: Barnes DJ (ed) Perspectives on coral reefs. Australian Institute of Marine Science, Manuka, A.C.T., Australia, pp 56-68

Crossland CJ (1987) In situ release of mucus and DOC-lipid from the corals Acropora variabilis and Stylophora pistillata in different light regimes. Coral Reefs 6:35-42

Crossland CJ, Barnes DJ, Borowitzka MA (1980) Diurnal lipid and mucus production in the staghorn coral Acropora acuminata. Mar Biol 60:81-90

Dalsgaard J, St John M, Kattner G, Muller-Navarra D, Hagen W (2003) Fatty acid trophic markers in the pelagic marine environment. Adv Mar Biol 46:225-340

Davey M, Holmes G, Johnstone R (2008) High rates of nitrogen fixation (acetylenen reduction) on coral skeletons following bleaching mortality. Coral Reefs 27:227-236
De Goeij JM, Van Duyl FC (2007) Coral cavities are sinks of dissolved organic carbon (DOC). Limnol Oceanogr 52:2608 2617

De Goeij JM, Moodley L, Houtekamer M, Carballeira NM, Van Duyl FC (2008a) Tracing ${ }^{13} \mathrm{C}$-enriched dissolved and particulate organic carbon in the bacteria containing coral reef sponge Halisarca caerulea: evidence for DOM-feeding. Limnol Oceanogr 53:1376-1386

De Goeij JM, Van den Berg H, Van Oostveen MM, Epping EHG, Van Duyl FC (2008b) Major bulk dissolved organic carbon (DOC) removal by encrusting coral reef cavities sponges. Mar Ecol Prog Ser 357:139-151

De Goeij JM, De Kluijver A, Van Duyl FC, Vacelet J, Wijffels RH, De Goeij AFPM, Cleutjens JPM, Schutte B (2009) Cell kinetics of the marine sponge Halisarca caerulea reveal rapid cell turnover and shedding. J Exp Biol 212:3892-3900

Erwin PM, Thacker RW (2007) Incidence and identity of photosynthetic symbionts in Caribbean coral reef sponge assemblages. J Mar Biol Ass UK 87:1683-1692

Ferrier-Pagès C, Leclerq N, Jaubert J, Pelegri SP (2000) Enhancement of pico-and nanoplankton growth by coral exudates. Aquat Microb Ecol 21:203-209

France RL (1995) Carbon-13 enrichment in benthic compared to planktonic algae: foodweb implications. Mar Ecol Prog Ser $124: 307-312$

France R, Holmquist J, Chandler M, Cattaneo A (1998) Delta N-15 evidence for nitrogen fixation associated with macroalgae from a seagrass-mangrove coral reef system. Mar Ecol Prog Ser 167:297-299

Fry B (2006) Stable isotope ecology. Springer, New York, p 308

Fry B, Lutes R, Northam M, Parker PL, Ogden JC (1982) A C-13/C-12 comparison of food webs in Caribbean seagrass meadows and coral reefs. Aquat Bot 14:389-398

Gast GJ, Jonkers PJ, Van Duyl FC, Bak RPM (1999) Bacteria, flagellates and nutrients in island fringing coral reef waters: influence of the ocean, the reef and eutrophication. Bull Mar Sci 65:523-538

Genin A, Monismith SG, Reidenbach MA, Yahel G, Koseff JR (2009) Intense benthic grazing of phytoplankton in a coral reef. Limnol Oceanogr 54:938-951

Ginsburg RN (1983) Geological and biological roles of cavities in coral reefs. In: Barnes D (ed) Perspectives on coral reefs. Australian Institute of Marine Science, Manuka, A.C.T., Australia, pp 148-153

Granek EF, Compton JE, Philips DL (2009) Mangrove-exported nutrient incorporation by sessile coral reef invertebrates. Ecosystems 12:462-472

Haas AF, Jantzen C, Naumann MS, Iglesias-Prieto R, Wild C (2010) Organic matter release by the dominant primary producers in a Caribbean reef lagoon: implications for in situ $\mathrm{O}_{2}$ availability. Mar Ecol Prog Ser 409:27-39

Hall D, Lee SY, Meziane T (2006) Fatty acids as trophic tracers in an experimental estuarine food chain: tracer transfer. J Exp Mar Biol Ecol 336:42-53

Harvey HR, Dyda RY, Kirchman DL (2006) Impact of DOM composition on bacterial lipids and community structure in estuaries. Aquat Microb Ecol 42:105-117

Hentschel U, Fieseler L, Wehrl M, Gernert C, Steinert M, Hacker J, Horn M (2003) Microbial diversity of marine sponges. In: Mueller WEG (ed) Molecular marine biology of sponges. Springer Verlag, Heidelberg, pp 60-88

Hill M, Hill A, Lopez AN, Harriott O (2005) Sponge-specific bacterial symbionts in the Caribbean sponge, Chondrilla caribensis (Demospongiae, Chondrosida). Mar Biol 148:1221-1230

Johannes RE (1967) Ecology of organic aggregates in the vicinity of a coral reef. Limnol Oceanogr 12:189-195 
Kim M-J, Choi J-S, Kang S-E, Cho J-Y, Jin H-J, Chun B-S, Hong Y-K (2004) Multiple allelopathic activity of the crustose coralline alga Lithophyllum yessoense against settlement and germination of seaweed spores. J Appl Phycology 16:175-179

Land LS, Lang JC, Smith BN (1975) Preliminary observations of the carbon isotope composition of some reef coral tissues and symbiotic algae. Limnol Oceanogr 20:283-287

Latyshev NA, Naumenko NV, Svetashev VI, Latypov YY (1991) Fatty acids of reef-building corals. Mar Ecol Prog Ser 76:295-301

Lee D, Carpenter SJ (2001) Isotopic disequilibrium in marine calcareous algae. Chem Geol 172:307-329

Lepoint G, Nyssen F, Gobert S, Dauby P, Bouquegneau J-M (2000) Relative impact of a seagrass bed and its adjacent epilithic algal community in consumer diets. Mar Biol 136:513-518

Lesser MP (2006) Benthic-pelagic coupling on coral reefs: feeding and growth of Caribbean sponges. J Exp Mar Biol Ecol 328:277-288

Lesser MP, Falcon LI, Rodriguez-Roman A, Enriquez S, HoeghGuldberg O, Iglesias-Prieto R (2007) Nitrogen fixation by symbiotic cyanobacteria provides a source of nitrogen for the scleractinian coral Montastraea cavernosa. Mar Ecol Prog Ser 346:143-152

Masood A, Stark KD, Salem N Jr (2005) A simplified and efficient method for the analysis of fatty acid methyl esters suitable for large clinical studies. J Lipid Res 46:2299-2305

Naumann M, Haas AF, Struck U, Mayr C, El-Zibdah M, Wild C (2010) Organic matter release by dominant hermatypic corals of the Northern Red Sea. Coral Reefs 29:649-659

Papina M, Meziane T, Van Woesik R (2003) Symbiotic zooxanthellae provide the host-coral Montipora digitata with polyunsaturated fatty acids. Comp Biochem and Physiol B-Biochem Mol Biol 135:533-537

Parnell A, Jackson A (2010) siar: stable isotope analysis in R.R package version 4.0.2. http://CRAN.R-project.org/package=siar

Parnell AC, Inger R, Bearhop R, Jackson AL (2010) Source partitioning using stable isotopes: coping with too much variation. PlosOne 5:1-5

Parrish CC, Abrajano TA, Budge SM, Helleur RJ, Hudson ED, Pulchan K, Ramos C (2000) Lipid and phenolic biomarkers in marine ecosystems. Analysis and applications. In: Wangersky P (ed) The handbook of environmental chemistry, vol 5, D. Marine chemistry, Springer-Verlag, Berlin, pp 193-223

Peterson BJ, Fry B (1987) Stable isotopes in ecosystem studies. Annu Rev Ecol Syst 18:293-320

Pile AJ (1999) Resource partitioning by Caribbean coral reef sponges: is there enough food for everyone? Mem Qld Mus 44:457-461

Raz-Guzman Macbeth A, De la Lanza Espina G (1991) Evaluation of photosynthetic pathways of vegetation, and of sources of sedimentary organic matter through $\mathrm{d} 13 \mathrm{C}$ in Terminos Lagoon, Campeche, Mexico. Anales Inst Biol Univ Nac Auton Mexico Ser Bot 62:39-63

Reiswig HM (1974) Water transport, respiration and energetics of three tropical marine sponges. J Exp Mar Biol Ecol 14:231-249

Reiswig HM (1990) In situ feeding in two shallow-water Hexactinellid sponges. In: Ruetzler K (ed) New perspectives in sponge biology. 3rd international conference on the biology of sponges. Woods Hole MA, Smithonian Inst Press, pp 504-510

Ribes M, Coma R, Atkinson MJ, Kinzie RA III (2003) Particle removal by coral reef communities: picoplankton is a major source of nitrogen. Mar Ecol Prog Ser 257:13-23

Ribes M, Coma R, Atkinson MJ, Kinzie RA III (2005) Sponges and ascidians control removal of particulate organic nitrogen from coral reef waters. Limnol Oceanogr 50:1480-1489

Richman S, Loya Y, Slobodkin LR (1975) The rate of mucus production by corals and its assimilation by the coral reef copepod Acartia negligens. Limnol Oceanogr 20:918-923
Richter C, Wunsch M (1999) Cavity-dwelling suspension feeders in coral reefs-a new link in reef trophodynamics. Mar Ecol Prog Ser 188:105-116

Richter C, Wunsch M, Rasheed M, Kötter I, Badran MI (2001) Endoscopic exploration of Red Sea coral reefs reveals dense populations of cavity-dwelling sponges. Nature 413:726-730

Ruetzler K, Duran S, Piantoni C (2007) Adaptation of reef and mangrove sponges to stress: evidence for ecological speciation exemplified by Chondrilla caribensis new species (Demospongiae, Chondrosida). Mar Ecol 28:95-111

Scheffers SR, De Goeij JM, Van Duyl FC, Bak RPM (2003) The cave-profiler: a simple tool to describe the 3D-structure of inaccessible coral reef cavities. Coral Reefs 22:49-53

Scheffers SR, Nieuwland G, Bak RPM, Van Duyl FC (2004) Removal of bacteria and nutrient dynamics within the coral reef framework of Curaçao (Netherlands Antilles). Coral Reefs 23:413-422

Scheffers SR, Nieuwland GN, Bak RPM, Van Duyl FC (2005) Why is bacterioplankton growth in coral reef framework cavities enhanced? Mar Ecol Prog Ser 299:89-99

Thurber AR (2007) Diets of Antarctic sponges: links between the pelagic microbial loop and benthic metazoan food web. Mar Ecol Prog Ser 351:77-89

Van den Meersche K, Van Rijswijk P, Soetaert K, Middelburg JJ (2009) Autochthonous and allochthonous contributions to mesozooplankton diet in a tidal river and estuary: integrating carbon isotope and fatty acid constraints. Limnol Oceanogr 54:62-74

Van Duyl FC (1985) Atlas of the living reefs of Curaçao and Bonaire Netherlands Antilles. Foundation for scientific studies in Surinam and the Netherlands Antilles, vol 117, p 37, 42 reef maps

Van Duyl FC, Gast GJ (2001) Linkage of small-scale spatial variations in DOC, inorganic nutrients and bacterioplankton growth with different coral reef water types. Aquat Microb Ecol 24:17-24

Van Duyl FC, Gast GJ, Steinhoff W, Kloff S, Veldhuis MJW, Bak RPM (2002) Factors influencing the short-term variation in phytoplankton composition and biomass in coral reef waters. Coral Reefs 21:293-306

Van Gaever S, Moodley L, Pasotti F, Houtekamer M, Middelburg JJ, Danovaro R, Vanreusel A (2009) Trophic specialisation of metazoan meiofauna at the Håkon Mosby Mud Volcano: fatty acid biomarker isotope evidence. Mar Biol 156:1289-1296

Vander Zanden MJ, Rasmussen JB (2001) Variation in $\delta^{15} \mathrm{~N}$ and $\delta^{13} \mathrm{C}$ trophic fractionation: implications for aquatic foos web studies. Limnol Oceanogr 46:2061-2066

Vasseur P (1974) The overhangs, tunnels and dark reef galleries of Tulear (Madagascar) and their sessile invertebrate communities. Proc 2nd Int Coral Reef Symp, p 143-160

Viso AC, Marty JC (1993) Fatty acids from 28 marine microalgae. Phytochemistry 34:1521-1533

Volkman JK (2006) Lipid biomarkers for marine organic matter. In: Volkman JK (ed) The handbook of environmental chemistry, vol 2. Springer, Amsterdam, pp 27-70

Wada S, Aoki MN, Tsuchiya Y, Sato T, Shinagawa H, Hama T (2007) Quantitative and qualitative analyses of dissolved organic matter released from Ecklonia cava Kjellman, in Oura Bay, Shimoda, Izu Peninsula, Japan. J Exp Mar Biol Ecol 349:344-358

Weisz JB, Hentschel U, Lindquist N, Martens CS (2007) Linking abundance and diversity of sponge-associated microbial communities to metabolic differences in host sponges. Mar Biol 152:475-483

Wild C, Huettel M, Klueter A, Kremb SG, Rasheed MYM, Jorgensen BB (2004) Coral mucus functions as an energy carrier and particle trap in the reef ecosystem. Nature 428:66-70

Wild C, Niggl W, Naumann MS, Haas AF (2010) Organic matter release by Red Sea coral reef organisms-potential effects on microbial activity and in situ O2 availability. Mar Ecol Prog Ser 411:61-71 
Wunsch M, Al-Moghrabi SM, Kötter I (2002) Communities of coral reef cavities in Jordan, Gulf of Aqaba (Red Sea). Proceedings of the 9th international coral reef symposium, pp 595-600

Yahel G, Sharp JH, Marie D, Haese C, Genin A (2003) In situ feeding and element removal in the symbiont-bearing sponge Theonella swinhoei: bulk DOC is the major source for carbon. Limnol Oceanogr 48:141-149

Yamamuro M, Kayanne H, Minagawa M (1995) Carbon and nitrogen stable isotopes of primary producers in coral reef ecosystems. Limnol Oceanogr 40:617-621 